\title{
PRODUCTION OF POTENTIAL FUNCTIONAL DAIRY PRODUCTS USING HERB TREATED BY MICROWAVE RADIATION
}

\author{
Kiss Kármen Anita ${ }^{1 *}$, Kapcsándi Viktória ${ }^{1}$, Posgay Miklós Marcel' ${ }^{1}$, Hanczné Lakatos Erika ${ }^{1}$ \\ ${ }^{1}$ Institute of Food Sciences, MÉK Faculty of Agriculture and Food Sciences, Széchenyi István University, \\ Hungary \\ https://doi.org/10.47833/2020.1.AGR.005
}

\section{Keywords: \\ microwave \\ functional food \\ cheese \\ rosemary}

\section{Article history:}

Received 16 Nov 2019

Revised 10 Dec 2019

Accepted 15 Dec 2019

\begin{abstract}
Our aim was to product potential functional dairy products (cheese) by adding microwave treated dried herbs to them. We worked out two methods to compare the antimicrobial effect of microwave and the microwave indicated heat treatment. The product technology was also worked out by us.
\end{abstract}

\section{Introduction}

Europe is a significant market of dried herbs and spices; Hungary is one of the most important suppliers [CBI]. $60-70 \%$ of the $35-40$ thousand tons of the produced drugs are exported [5]. These products are commonly used in dried form. For their microbiological decontamination using ionizing radiation is authorized by the Regulation (EC) No. 1993/3, although their consumption in food products -which do not require further processing-could mean significant risk from the aspect of food safety [8]. However, dried herbs have low water activity, and due to this, they do not favor the growth of the pathogenic microorganisms after the rehydration of these matrixes could mean significant risk factors to food safety [4].

There are not extensive literature data about the microbiological decontamination of the dried herbs and spices, furthermore it is unclarified whether the sterilizing effect is primarily caused by the heat treatment [13], induced by the microwave generated changes of the water molecule's rotation and friction [11] or to the non-thermal effect of microwave [2; 3; 7].

One of the aims of our study was to produce by our developed technology cheeses and develop a potentially functional food with the addition of the microwave treated herbs. We tried to determine that is there any detectable inhibitory effect of the added herb on the number of microorganisms and in this context, the shelf life of the products [10].

Our study's main purpose was creating a microbiological stable product using microwave treatment on $2.45 \mathrm{GHz}$ frequency, applying lower performance value $(900 \mathrm{~W})$ like it has been used in the connecting literature [7].

\section{Materials and methods}

Our herb samples (Gusto Dried Rosemary from Házi Piros Paprika Inc.) were treated by MARS (CEM) microwave system. By the microbiological measurements, we used media from Biolab and Merck, incubating of the samples, and the final products were carried out in BINDER 720 thermostat. The milk was pasteurized and then coagulated in pre-sterilized medium melting equipment (Super Exclusive). To optimize the milk's calcium content and to avoid bloating, we used $\mathrm{CaCl}$ (Molar

\footnotetext{
* Corresponding author. Tel.: +36 704195259

E-mail address: kiss.karmen.anita@sze.hu
} 
Chemicals Inc.) and KNO3 (Tetra Chemicals Europe AB). By the production of cheeses, we used CHY-MAX rennet (CHR Hansen) and FD-DVS CHN-22 mesophilic aroma forming culture (CHR Hansen). For packaging the cheeses, we used micro-vacuum technology (GOURMET N70) using a nitrogen-containing shielding gas. We used Stomacher Homogenizer to homogenize each of the cheese samples.

\subsection{Sample preparation}

We filled the test tube of the microwave system with $50 \mathrm{~mL}$ sterile dilution water, then sterilized the tubes in the „Standard Control” mode on $600 \mathrm{~W}$ performance value for $1 \mathrm{~min}$. We replicated this method three times until the temperature of the sterilizing water reached $100^{\circ} \mathrm{C}$, then we left them to cool down.

We have measured $3 \mathrm{~g}$ of dried rosemary on the analytic scale into the pre-sterilized tubes of the microwave system. Then deionized water was filled into them in a $1: 10$ ratio $(27 \mathrm{~mL})$ by using a pipette. During our experiment, we were working with six samples with three parallel samples per sample. We also created a control (ROSM K), by measuring $5 \mathrm{~g}$ of the dried rosemary and pipetting deionized water to it in the same ratio, as we used by the samples, but we left the control standing for an hour to being wet, or else the dried rosemary would damage the Stomacher packet.

We have planned to carry out storage life examination by left he cheese ripen for five weeks, but eventually, we need to stop our examination after three weeks. We took $5 \mathrm{~g}$ from the cheese samples, then added deionized water to them, then homogenized them in Stomacher Homogenizer.

\subsection{Microwave treatment of herbs}

For the microwave treatment of the herbs, the plastic tubes were filled with our samples, then covered and sealed, eventually placed into their holders. We have worked out two microwave treating methods to compare the microwave radiations and heat treatment's - was generated by microwave treating - effects on the numbers of microorganisms.

First, we worked in the „Ramp to Temperature” mode, where samples were controlled for $50^{\circ} \mathrm{C}$ upper- temperature limit. We also used a $30 \mathrm{~s}$ time limit too to the heat of the samples reach $50^{\circ} \mathrm{C}$. On this temperature value, the samples were held one more minute. We indicate them with an ' $\mathrm{H}$ '.

The other setting we used was „Standard Control”, where we did not apply neither temperature nor time limit.

We worked with two parallel rows of samples, using 400W, 500W, and $600 \mathrm{~W}$ performance value on $2.45 \mathrm{GHz}$ frequency. Three samples were treated for 30 seconds controlled by upper temperature limit, the other three samples were treated by microwave on the same performance values, but the treatment took 60 s.

\subsection{Microbiologically measurements of the herbs and milk samples}

Then we inoculated $1 \mathrm{~cm}^{3}$ from the microwave treated and from the untreated control samples, from the raw, unpasteurized milk and from the storage pre-pasteurized $1,5 \%$ fat contained milk, from the post-pasteurised unified milk and from the post-salting and formed fresh cheeses too into Petri dishes, then plated Plate Count (PC - total cell count), Chromocult Coliform (CC - coliform and E. coli), Yeast Extract Glucose Chloramphenicol (YGC - mold and yeast) media on them. In the case of Baird Parker (BP), we superficially spread a $0.1 \mathrm{~cm}^{3}$ sample on pre-cast mind solidified media. Samples on PC media were 72 hours at $30^{\circ} \mathrm{C}, \mathrm{CC} 24-48$ hours (until typical colonies appeared) and YGC 96 hours at $26^{\circ} \mathrm{C}$, BP media $24-48$ hours (typical colonies) at $37^{\circ} \mathrm{C}$ incubation was used.

The dried plant samples were also tested for the presence of Salmonella spp. (on XLD agar, Xylose Lysine Deoxycholate) moreover, mesophilic spore bacteria (on TSC agar, Tryptose sulfite cycloserine), but the rosemary samples contain none of these pathogenic microorganisms.

In our microbiological examinations, we took into account the microorganism groups defined in Decree 4/1998 (XI.11.) EüM and compared our results with the values of the decree for raw milk, pasteurized milk, dairy products (cheese) and dried herbs.

The results were obtained by subjective colony count and then by weighted mean colony count $(\bar{C})$, expressed in CFU/g. Plates with developed colonies between 10 and 300 were included in the evaluation. The values were compared with those specified in Decree 4/1998 (XI.11.) EüM [1]. 
The total colony count of milk -purchased from a public milk vending machine- was extremely high - even after the third dilution - more than 300 colonies have been weighted on average of 3.2 * $10^{5} \mathrm{CFU} / \mathrm{g}$. The pre-pasteurized store milk microbiological parameters complied with the regulation (4/1998 EüM). The pasteurization we used at $75^{\circ} \mathrm{C}$ for $15 \mathrm{~min}$ reduced the Staphylococcus aureus and coliform's number to zero and the total colony number of the pasteurized mixture decreased to $3^{*} 10^{2} \mathrm{CFU} / \mathrm{g}$. The milk samples did not contain mesophilic spore-forming bacteria or Salmonella spp.

\subsection{Food production's method}

We used $10 \mathrm{~L}$ of milk during the production, and we expected to have $1 \mathrm{~kg}$ of cheese from this amount. Our aim was to produce Trappist like cheeses, those them $2.9 \%$ fat milk was required, obtained from raw milk (public milk vending machine) (3.6\%) and $1.5 \%$ skimmed milk (commercially available) at the following blending ratio; $6.67 \mathrm{~L}$ of raw milk and $3.33 \mathrm{~L}$ of $1.5 \%$ commercially, pasteurized skimmed milk. For calculation of the fat value, we have used the equation below:

$$
10 L * 2,9 \%(\text { targeted fat contain })=29 \mathrm{FV}(\text { fat value })
$$

The $10 \mathrm{~L}$ of mixed milk was then heated to $75^{\circ} \mathrm{C}$ in a pre-sterilized medium melting equipment, and kept at this temperature for 15 minutes. To verify the samples's $\mathrm{pH}$ value, we used a $100 \mathrm{~mL}$ borosilicate bottle, as a test flask during coagulation.

The milk was then allowed to cool (to $40^{\circ} \mathrm{C}$ ), and then $1 \mathrm{~g}$ potassium-nitrate and $1 \mathrm{~g}$ calciumchloride were added. After the milk temperature cooled down to $32^{\circ} \mathrm{C}$, we added $0.2 \mathrm{~g}$ of FD-DVS CHN-22 mesophilic aroma-forming culture to it.

Subsequently, the lactic acid bacteria were allowed to acclimatize for one hour while maintaining the milk temperature at $32-37^{\circ} \mathrm{C}$, and after that, we inoculated $2.5 \mathrm{~mL} \mathrm{CHY}$-MAX rennet on $36.6^{\circ} \mathrm{C}$. The $\mathrm{pH}$ of the milk before inoculation was 6.6 and remained at the same value after inoculation. After one hour of the curdling, the $\mathrm{pH}$ of the sample did not decrease significantly (6.5), but in contrast to our previous work, the curdling method occurred within 1.5 hours instead of 2-3 hours.

After coagulation, the curdled milk was chopped with cheese harp, then $30 \%$ of the whey was separated, then $14 \%$ of this volume was replaced with $45^{\circ} \mathrm{C}$ water to wash the curd. The whey was then separated and the curd was immersed in $25 \mathrm{dkg}$ plastic cheese molds, sterilized in hot water; we filled a total of eight molds, and the weight of the resulting cheeses after pressing and salting was $241 \mathrm{~g}$ on average, so we were able to obtain more final products than expected (from 10L milk, we'd got $1.93 \mathrm{~kg}$ of cheese).

We've added microwave treated, and non-treated herb to the curds in the molds. The ratio of the herbs were $0.5 \%$ of relating to the weight of the curds. Our cheese samples were named according to the applied microwave treatment of the added herb; ROSM H 400/30; ROSM H 500/30; ROSM H 600/30; ROSM 400/60; ROSM 500/60; ROSM 600/60 and an untreated herb contained control sample (ROSM K). As a control, we prepared a so-called "blank" sample, a cheese without added herb.

The filled molds were covered with matching stainless steel press plates and placed one at a time in a fruit presser for 5-5 minutes per sample. We pressed the samples until the curd had already started to pass through the perforations of the cheese molds. After pressing, we removed the curd clumps from the perforation and then took off the finished cheeses out of the molds. After that, they dried for 17 hours, then the cheeses were quartered and soaked in $20 \%$ brine for 2 hours.

After the salting, the quartered pieces were individually packaged at the Hungarian Dairy Experimental Institute, using a micro-vacuum technique with a GOURMET N70 system, applying nitrogen-containing shielding gas. The ripening was carried out at $15^{\circ} \mathrm{C}$, in a thermostat.

The cheeses were labeled and inoculated for three weeks, during which the changes in total colony number (PC), coliform (CC), yeast/mold (YGC) and Staphylococcus aureus (BP) colony count were examined. Since the milk samples, as well as the herb samples, were negative for Salmonella spp. and Clostridium spp., we did not perform these tests on the finished products. 


\section{Results and discussion}

During the treatment of dried herbs, the total colony number of untreated control sample (ROSM K) was $2^{*} 10^{3} \mathrm{CFU} / \mathrm{g}$. In the case of samples without upper heat limit, by increasing the performance, the total colony count decreased $\left(2.11^{*} 10^{3} \mathrm{CFU} / \mathrm{g}-1.8^{*} 10^{2} \mathrm{CFU} / \mathrm{g}\right)$, but by the samples controlled at $50^{\circ} \mathrm{C}$ upper heat limit, this value was way higher, than the control sample's value.

We inoculated the cheese samples on the third day after the production. By the samples, which were added by rosemary treated by microwave without heat control, we observed a decrease in the number of the colonies, but the CFU value of the $400 / 60$ sample was higher $\left(7.2^{*} 10^{5} \mathrm{CFU} / \mathrm{g}\right)$, than the control sample's value $\left(5.9^{*} 10^{5} \mathrm{CFU} / \mathrm{g}\right)$. The increase in total colony number by two orders of magnitude indicates, that the product we produce serves as a suitable medium for the growth of microorganisms derived from the herbs. Besides, the cheese culture's lactic acid bacteria also cause further growth.

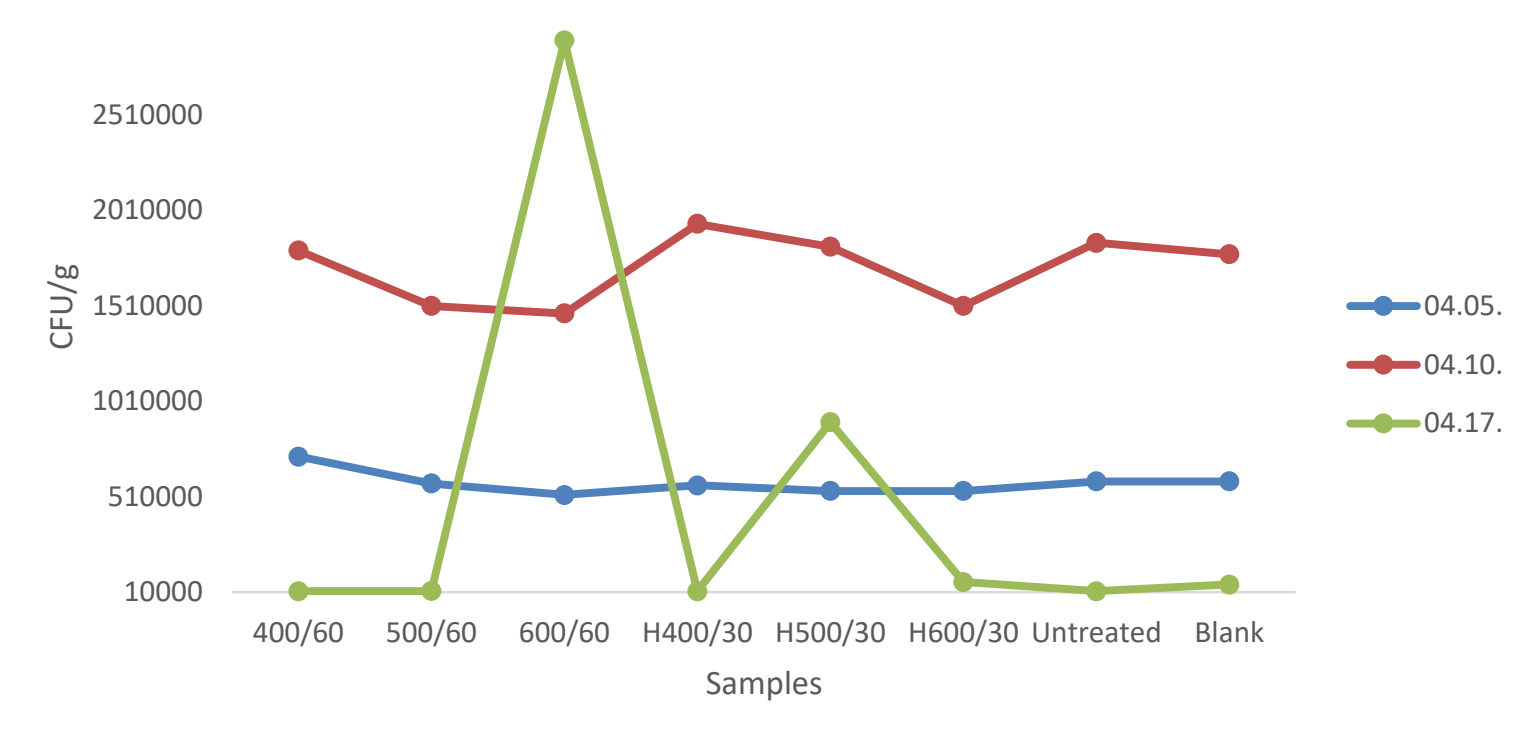

Figure 1. Total plate count on PC agar between 04.05.-04.17. $\left(10^{4}-10^{6} \mathrm{CFU} / \mathrm{g}\right)$

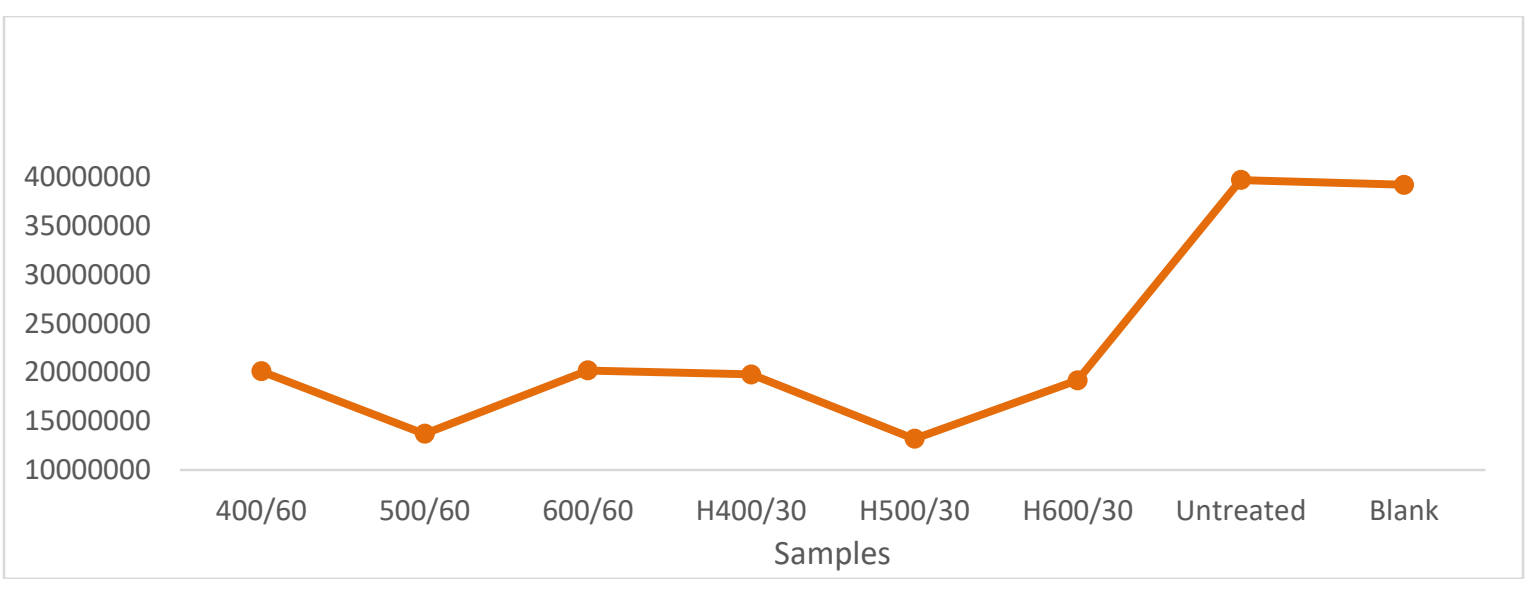

Figure 2. Total plate count on PC agar on 04.24. $\left(10^{7} \mathrm{CFU} / \mathrm{g}\right)$

By the examination of the coliform, colony-forming units in dried rosemary samples treated by upper heat limit controlled microwaving method, the CFU of the samples were higher $\left(3.2^{*} 10^{3} \mathrm{CFU} / \mathrm{g}\right.$ $\left.-5.6^{*} 10^{3} \mathrm{CFU} / \mathrm{g}\right)$ than we counted in the untreated herb sample $\left(1.7^{*} 10^{2} \mathrm{CFU} / \mathrm{g}\right)$. By the first examination of the cheeses, the dispersion of the number of the coliform bacteria's CFU was random between $2.08 * 10^{4} \mathrm{CFU} / \mathrm{g}-2.73^{*} 10^{4} \mathrm{CFU} / \mathrm{g}$. The cheese sample's $\mathrm{pH}$ value was $6.1-6.3$, we assumed, that this value did not inhibit the growth of the coliforms. The coliform number of the blank $\left(1.49^{*} 10^{3} \mathrm{CFU} / \mathrm{g}\right)$ and the untreated rosemary contained cheeses $\left(1.49^{*} 10^{4} \mathrm{CFU} / \mathrm{g}\right)$ were lower, but during the ripening process, their coliform numbers increased (blank sample $9,8^{*} 10^{3} \mathrm{CFU} / \mathrm{g}$; ROSM 
$\left.\mathrm{K} 8,3^{*} 10^{3} \mathrm{CFU} / \mathrm{g}\right)$. In the case of those cheeses, which were added by herbs, treated without heat limit, the coliform number started to decrease with the increasing of the performance and by the decreasing of the $\mathrm{pH}$ value. At the third week, only the H500/30 and the H600/30 samples corresponded to the limits for coliforms in the Regulation 4/1998.

During the treatment of dried rosemary, mold growth $\left(<1^{*} 10^{1} \mathrm{CFU} / \mathrm{g}\right)$ was observed in samples with a heat barrier, and by the control sample. Mold colonies did not develop in samples without heat barrier $\left(50^{\circ} \mathrm{C}\right)$. No yeast growth was observed in any of the samples.

During the treatment of dried rosemary, mold growth $\left(<1^{*} 10^{1} \mathrm{CFU} / \mathrm{g}\right)$ was observed in samples with a heat barrier, and the control sample. Mold colonies did not develop in samples without heat barrier. No yeast growth was observed in any of the samples.

In the case of samples of cheeses inoculated with treated plants, the number of molds was generally higher than that of blind and untreated herbal cheeses. No characteristic pattern was observed in mold development. Their number did not show any regularity decreasing with $\mathrm{pH}$.

During the storage test, quartered cheese samples were packed by micro-vacuum technology and were ripened in thermostat at $15^{\circ} \mathrm{C}$. It seems, that this condition was favorable for the microorganisms originated from the added dried herbs. Their numbers increased substantially. Initially, we attributed this to the presence of the culture forming microorganisms.

With the progression of the storage test, the number of mold colonies stagnated between $10^{2}$ $-10^{4} \mathrm{CFU} / \mathrm{g}$, exceeding the rejection limit of the relevant regulation. No yeast growth was observed.

In the third week of the storage test, the total number of the coliform bacteria decreased at least with two magnitudes, compared to the number, we measured in the previous weeks. In the case of two samples (H500/30; H600/30), the coliform's number dropped below the acceptable limit of 4/1998. EüM regulation. Our dairy product's $\mathrm{pH}$ value $(\mathrm{pH} 5.7)$ was slightly above the value (pH 5.2-5.3), we expected from the semi-hardened cheeses.

\section{Conclusion}

In conclusion, the microbiological parameters of the dairy products we created by our technology did not meet the regulations of the 4/1998 Decree, since the number of the coliform bacteria - except for two samples - and the total number of the mold colonies exceeded the microbiological limit.

However the total colony number of the semi-hardened cheeses is not regulated by the 4/1998 Decree, we found the total plate count too high $\left(>1^{*} 10^{7} \mathrm{CFU} / \mathrm{g}\right)$ on the third week, not to mention, that this value was with three magnitudes higher, than the value we measured on the second week. So we consider, that continue the storage test isn't necessary.

The microwave treatment without upper heat limit proved to be suitable for decreasing the total colony number of the dried herb samples, we did not find regularity in the colony number's changing by those samples, which were treated by microwave in the Ramp to Temperature mode. We have tried to create potential functional dairy products by adding microwave treated herbs, but they increased the microbiological contamination of the final product, and we did not observe the inhibitory effect of the dried rosemary samples at the power values below the recommended $900 \mathrm{~W}$ (400W; 500W; 600W).

So our methods need further development and we aim to find herbs, whose antimicrobial activity can be traced in the products we'll create.

\section{Acknowledgment}

Acknowledgments to project EFOP-3.6.2-16-20-20-2017-00012: "Developing a Functional, Healthy and Safe Food Tracking Model from the Farm to the Table". 


\section{References}

[1] 4/1998. (XI. 11.) EüM rendelet; 1. számú melléklet - Élelmiszerek mikrobiológiai vizsgálata és megítélése; 2 . számú melléklet - Az élelmiszer megítélését befolyásoló kórokozók; 4. számú melléklet - Az élelmiszer-előállítás belső minőségellenőrzését szolgáló mikrobiológiai vizsgálatok és ajánlott határértékek

[2] BARNES, F.S., HO, C.L. (1977) Model for some Nonthermal Effects of Radio and Microwave Fields on Biological Membranes. IEEE Transactions on Microwave Theory an Techniques, vol 25, pp.742-746.

[3] BASARAN, P., AKHAN, Ü. (2010) Microwave Irradiation of Hazelnuts for the Control of Aflatoxin Producing Aspergillus parasiticus. Innovative Food Science and Emerging Technologies, vol 11, pp.113-117.

[4] BEUCHAT, L.R., KOMITOPOULOU, E., BECKERS, H., BETTS, R.P., BOURDICHON, F., FANNING, S., JOOSTEN, H.M., KUILE, B.H.T. (2013) Low-Water Activity Foods: Increased Concern as Vehicles of Foodborne Pathogens. Journal of Food Protection, vol 76 (1), pp.150-172.

[5] BORBÉLYNÉ, H.É., KUTASY, E. (2012) Gyógynövények Termesztése és Feldolgozása. Növénytudományi Intézet, Debrecen

[6] CBI INFORMATION DATABASE (2015) CBI Trade Statistics Spices and Herbs. CBI Ministry of Foreign Affairs, pp. $1-8$.

[7] DABABNEH B.F. (2013) An Innovative Microwave Process for Microbial Decontamination of Spices and Herbs. African Journal of Microbiology Research, vol 7 (8), pp. 636-645.

[8] EUROPEAN COMMISSION (2012) A Bizottság Jelentése az Európai Parlamentnek és Tanácsnak - A 2009. Évre Vonatkozóan az lonizáló Sugárzással Kezelt Élelmiszerekről és Élelmiszer-Összetevőkröl, pp.2-21.

[9] KOZEMPEL, M., SCULLEN, O.J., COOK, R., WHITING, R. (1997) Preliminary Investigation Using a Batch Flow Process to Determine Bacteria Destruction by Microwave Energy at Low Temperature. Lebensmittel-Wissenschaft und -Technologie, vol 30, pp. 691-696.

[10] KUBRA I.R., KUMAR D., RAO L.J.M. (2016) Emerging Trends in Microwave Processing of Spices and Herbs. Critical Reviews in Food Science and Nutrition, vol 56, pp. 2160-2173.

[11] SCHIFFMANN, R.F. (2010) Industrial Microwave Heating of Food: Principles and Three Case Studies of its Commercialization.Woodhead Publishing, RF Schiffmann Associates Inc., USA, pp.407-425.

[12] SALVATORELLI, G., MARCHETTI, M.G., BETTI, V., ROSASPINA, S., FINZI, G. (1996) Comparison of the Effects of Microwave Radiation and Conventional Heating on Bacillus subtilis spores. Microbios, vol 87, pp.169-174.

[13] SHAZMAN, A., MIZRAHI, S., COGAN, U., SHIMONI, E. (2007) Examining for possible nonthermal effects during heating in a microwave oven. Food Chemistry, vol 103, pp. 444-453. 